\title{
Nutritional Deficiency and Acquired Ichthyosis
}

\author{
Samuel B. Holzman, MD and Samuel C. Durso, MD, MBA
}

Johns Hopkins University School of Medicine, Baltimore, MD, USA.

KEY WORDS: acquired ichthyosis; ichthyosis; nutritional deficiency; malnutrition.

J Gen Intern Med 32(10): 1161-1162

DOI: $10.1007 /$ s11606-017-4070-6

(C) Society of General Internal Medicine 2017

A 63-year-old man with a remote history of oropharyngeal cancer presented with a 1-year history of dysphagia, poor oral intake, and a 50-pound weight loss. On exam, he appeared cachectic with diffuse, symmetric scaling, most prominent over his lower extremities (Fig. 1a). He denied associated pain or pruritus. Laboratory testing revealed an undetectable vitamin $\mathrm{C}$ level and markedly reduced levels of A, E, B1, and B6. Given his malnourished state, enteral nutrition via a percutaneous gastrostomy tube was initiated. His skin findings were thought to represent a form of acquired ichthyosis (AI) related to nutritional deficiency. Over time, he gained weight and his skin findings progressively improved, with complete resolution by month 6 (Fig. 1b).

Acquired ichthyosis is a non-hereditary cutaneous disorder characterized by rough, dry skin with prominent scaling. ${ }^{1}$ Skin changes are the result of hyperkeratosis due to disruption of epidermal cornification. The underlying mechanism is debated, though impaired lipogenesis has been proposed. ${ }^{2} \mathrm{AI}$ is often associated with systemic disease, ${ }^{6}$ including malignancy, autoimmune disease, and nutritional deficiency, in the form of either gross protein-energy malnutrition ${ }^{3}$ or vitamin deficiency. ${ }^{4,5}$ The diagnosis is generally clinical, and treatment targets the underlying disease state, though lipid-rich lubricants and keratolytic agents can be useful adjuvants. ${ }^{1}$
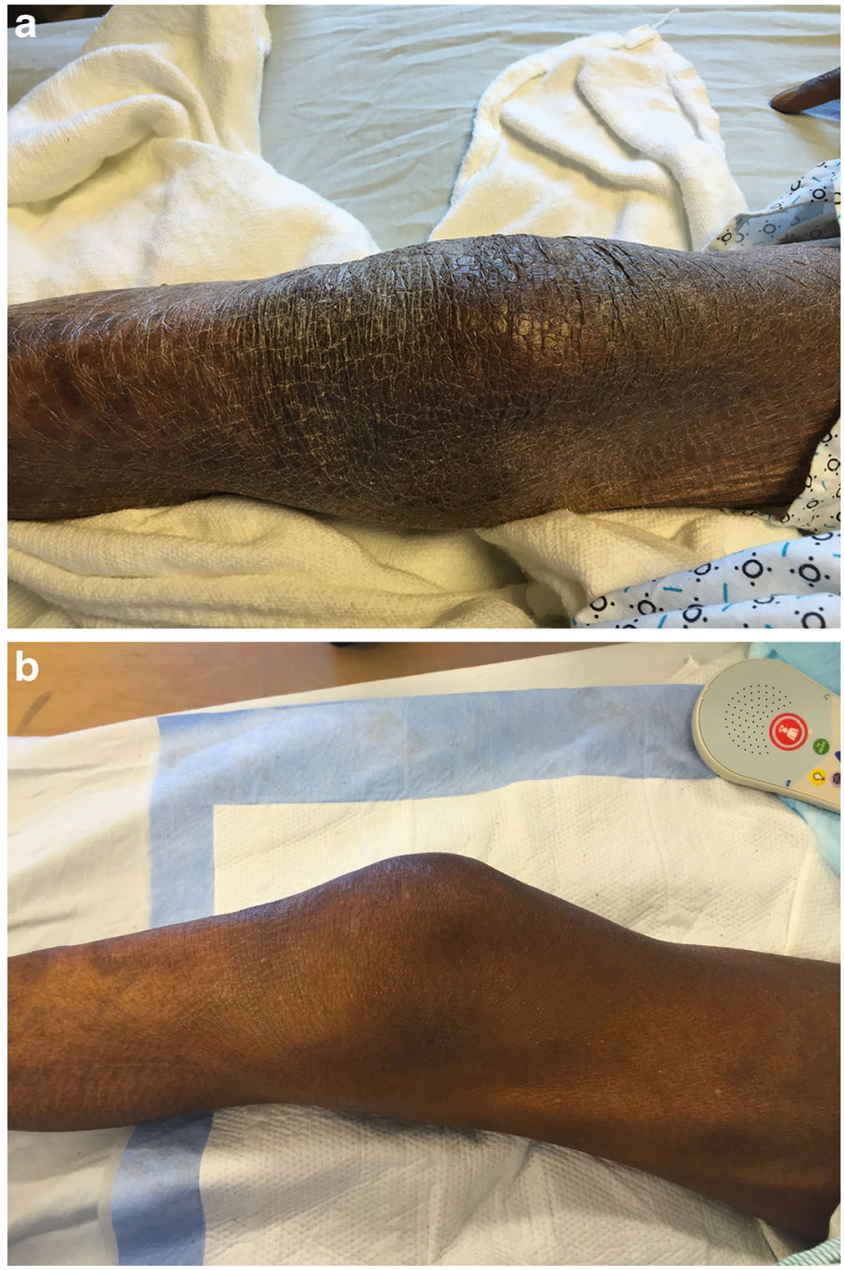

Figure 1 Skin findings before and after nutritional supplementation.

Received January 30, 2017

Revised April 3, 2017

Accepted April 17, 2017

Published online May 3, 2017 
Corresponding Author: Samuel B. Holzman, MD; Johns Hopkins University School of Medicine, Baltimore, MD, USA (e-mail: Sholzma1@jhmi.edu).

\section{Compliance with Ethical Standards:}

Funding: This work was supported by the National Institute of Health T32 AIO07291-27 to SH. The content is solely the responsibility of the authors and does not necessarily represent the official views of the National Institutes of Health.

Conflict of Interest: The authors declare that they do not have a conflict of interest.

\section{REFERENCES}

1. Patel N, Spencer LA, English JC, Zirwas MJ. Acquired ichthyosis. J Am Acad Dermatol. 2006;55(4):647-656.

2. Okulicz JF, Schwartz RA. Hereditary and acquired ichthyosis vulgaris. Int J Dermatol. 2003;42:95-98.

3. Gupta S, Singh S. Secondary ichthyosis: report of 2 cases. Indian J Med Sci. 1989; 43(4):92-94.

4. Hyman G. Treatment of ichthyosis. Arch Derm Syphilol. 1945;52(3):178179.

5. Aram H. Acquired ichthyosis and related conditions. Int $\mathrm{J}$ Dermatol. 1984;23:458-461.

6. DiGiovanna JJ, Robinson-Bostom L. Ichthyosis: etiology, diagnosis, and management. Am J Clin Dermatol. 2003;4(2):81-95. 